\title{
End of an Era
}

\section{Welcome by the Editor-in-Chief}

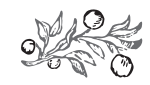

Journal of Economic Literature (JEL) codes: A1, B00, F01, N00, O1

Keywords: economic development, geopolitics, Roman Empire, Republic of Venice, United States, Communist Manifesto, European Union, People's Republic of China, Hungary

Human history may be divided into numerous phases. The most important division line is between the eras preceding and following the birth of Jesus Christ, the Messiah, but if economic development and its epicentres and the power-related and cultural influence are also considered as era markers, the ancient civilisations can be defined as the oldest era. Typically we reach back to the polities established along the rivers Tigris, Euphrates and Nile, but ancient China, namely the period between the 18th century and 220 B.C. in Chinese history, roughly corresponding to the period we call Antiquity in the Middle East and Europe, also comes under this heading. The ancient period of Chinese history is preceded by Chinese prehistory and followed by Chinese Middle Ages, also termed as Middle Imperial China (220-1368). For minor nations optimum relations with empires and to the mainstream was and has remained literally vital.

The series of eastern political entities, spanning several thousands of years, served the development of mankind by numerous technical achievements and intellectual ammunition, just as the civilisation established and existing for long centuries in the pre-states (Upper and Lower Egypt) and then in the state of the Egyptian Empire was by far the longest living culture in history, as it was capable of surviving for more than four thousand years between the 4th millennium B.C. and the Arab conquest in 641 A.D. The Nile Valley was a natural ecological corridor stretching from the central areas of Africa to the north, where, similarly to other ancient states, the administration of the empire established a work organisation that can be termed developed and efficient at the standard of the time. Egypt reached the peak of its power in 1532 B.C. During the reign of Thutmose III, it grew to become a world empire with its stateof-the-art army having a pivotal role. At that time Egypt had an influence on an area from the Fourth Cataract of the Nile in the south to the River Euphrates. As a result of the domestic crisis caused by the religious reforms of Pharaoh Akhenaten, the conquered Asian lands were lost and the empire was compelled to defend itself against the Hittites. The empire began to decline. 


\section{End of an Era - Welcome by the Editor-in-Chief}

The Roman Empire was a polity established by ancient Rome in the Mediterranean. The term "Roman Empire" has a double meaning. It the empire is considered as an independent state organisational entity, the state of Rome had already met its criteria by the 3rd century B.C., when it had unified Italy and launched conquests in the Mediterranean, on the Balkan, and on the Iberian Peninsula. If, however, the term 'empire' is merely considered as a synonym for the rule of emperors, then the Roman Empire starts with the establishment of the principate by Caesar Augustus, strictly speaking, from 27 B.C. The Imperium Romanum reached its largest expanse under Trajan, encompassing an area of nearly six million square kilometres, including Europe to the line of defence along the River Danube, North Africa, and the Middle East to as far as Mesopotamia, Asia Minor and the northern coasts of the Black Sea. The Roman Empire spanned an era in the development of mankind and it had an impact on the entire world known at that time. All roads began in Rome and led to Rome.

The western part of the Roman Empire - and the method of production built on slavery - began to disintegrate in 395 A.D., after the division of the empire into two. The western and the eastern empires were unable to join forces to withstand barbarian attacks. They agreed with the wandering ethnic groups to the detriment of each other. The Western Roman Empire lost its provinces one by one. In 451 A.D. Attila the Hun and his associates crossed the River Rheine and the Roman legions had a difficult time to halt him. The collapse of the empire was inevitable, not so much because of the exhaustion of its army but due to the frail economy of the state that backed it. Although for centuries Rome was the centre of western civilisation, culture, religion, political development and arts, it never regained this role in its former glory after the repeated attacks.

The "region's" next and last political formation that had a global impact (although in a more modest imperial size but still notable in terms of its impact) was the Republic of Venice, in the period between the 8th century A.D. and 1797. The merchant state developed around the city of Venice obtained vast areas in its ownership, primarily through the economic influence of trade organisation. In addition to its leading role in the region, through its financial and trading power, the "Queen of the Adriatic Sea" was also capable of setting up an energising cooperation between continents known to Europeans at the time. Actually, the Apennine Peninsula gave the world two empires stretching beyond its own geographical borders: a slaveholding and a merchant empire, the latter being the precursor of the subsequent empires that became increasingly business-driven over the centuries. With the fall of Venice, the global mainstreams shifted out of the Mediterranean to the North Atlantic region, to the American continent, which was, however, catalysed by the intellectuals of the developed Europe.

The next era undoubtedly began with the discovery of America, its occupation and turning it into an economic power centre. Christopher Columbus was a traveller and a navy officer of Italian extraction, who served first the Portuguese and then the Spanish crown and explored the American continent in 1492. Although the first Europeans who stepped on American soil were Vikings in the 10th century, in terms of 
cultural history and economy, the discovery launched by Columbus at the end of the 15 th century was the predominant one, as this led to the rapid expansion of the contemporary worldview and triggered the mapping and colonisation of the American continent. A further impetus was given to the market and economic developments that began in the late 15 th century by the invention that converted steam energy into mechanical work, or the improvement of the first genuine steam engine in 1769. The application of James Watt's invention in industrial systems resulted in the transformation of production, improved efficiency and the establishment of capitalist large factories that replaced guilds, craft production in manufactures and the organisations built on them. The use of steam stepped up production by several magnitudes, multiplied production capacities, and industrialised the areas that had been politically subdued and made into nearly unlimited market outlets in the course of colonisation.

This new world order needed multiple times more capital, production capacity, market outlets and, not in the least, masses of workers to operate the system than guild manufacturing characteristic of the period between the 16th and 18th centuries. The emergence of capital and market factors entailed the disintegration of feudal societies, the subjugation of less developed parts of the world, and the appreciation of industrial labour. Thus, after a certain level, higher profit could only be achieved by increasing workers' capacity while disproportionately (more moderately) raising the wage paid for it, and so the operator of the system, i.e. workers also recognised the significance of enforcing their rights. Before long, an intellectual trend evolved that has been affecting our opportunities and future and has been shaping the fate of empires since the end of the 19th century, and throughout the entire 20th century, up to now. The Communist Manifesto, the joint product of Karl Marx and Friedrich Engels, was published in February 1848, and became the official party programme for the Communist League. Its upswing commenced after the First International and the Paris Commune, it became fully fledged after the 1917 October revolution in Russia, and spread worldwide in the decades that followed World War II, through the operation of the state organisations and ideologies in Central and Eastern Europe and in the nations that wished to be liberated from colonialism in Africa, Asia and Latin America. Saturated by this idea, the world war turned into a revolution, and then a new world war broke out, and brought about the uninterrupted preparation for war by both the capitalist and the socialist blocs, the United States and the Soviet Union for fifty years. The enforcement of its ideology did not come to an end when the Soviet Union and the soviet bloc disintegrated, as the operation of one of the most prominent states of the world, the People's Republic of China is primarily based on this economic theory and regularly makes outstanding achievements.

China is the oldest living civilisation of the world. The world empire that is the only one still capable, after thousands of years of splendour, of seeking to rise to global power once again. From 221 B.C., it developed as an independent cultural unit, under the leadership of various dynasties, cut off from western empires, up to the 19th century, when the British Empire brought it under a quasi-colonial rule. Up to the middle of the 20th century, it operated at the mercy of medium powers in the Far East. 


\section{End of an Era - Welcome by the Editor-in-Chief}

But today, China is the third most important military, second ranking economic and most populous state of the world. Although slowing, its economic growth is unbroken, and what is more, it is capable of continuously expanding its upstream and export markets. In addition to having its goods export dominate economically important regions, it is even capable of investing capital, and moreover, it has a pivotal role in financing the government debt of the United States. China has recognised that it will only be able to maintain its dominant position in growth, which is the very basis of its global influencing role, by a massive foreign economic expansion. Currently, efforts are made at "getting into orbit", and so in addition to repeatedly going to trade wars with the No. 1 economic power of the world (the United States), after having seized the raw materials bases in Africa, the People's Republic of China makes efforts at occupying strategic positions in the European Union, cooperating with the Member States in the region. This means that the new power and the economic impetus come from Europe. Not from the weakening euro area, not from the United States, which has insufficient raw material bases and produces at high costs, but for the most part from China. China, where the economy is increasingly guided by market considerations controlled by political governance endeavouring to obtain a dominant position in the world. Where the state has a proactive economy-influencing role with strong regulatory and control powers. Where economic planning is predominant in a planned economy interwoven with market elements, naturally, fully fledges, raised to a large scale, in a model we Hungarians made attempts at in 1968, in the framework of the New Economic Mechanism. It failed in Hungary, and has been successfully applied in China.

In the economic environment reorganised after 2010, the state has adopted a proactive role in influencing the economy. The appreciation of its role is also recognisable from the (re)possession of the strategic sectors given into foreign private ownership decades ago. In order to improve the quality of life for the population, the government has taken measures for wage and income hikes and began to reduce the prices of public utility services. Its role in regulating and controlling market participants and public institutions has appreciated. But let us also remember our Russian and Central Asian friends, who also have governments with strong economy influencing roles. In other words, in the countries of the circle of new allies the economy is managed in a way that is very similar to the Hungarian practice, which facilitates cooperation.

The reader may wonder what the purpose of this brief outline analysing the operation of empires retrospectively to a few thousand years is. Obviously, to provide considerations for mapping Hungary's opportunities in 21st century, for the formulation of visions and for guiding the Hungarian economy in the global economy. Appropriate alignment is a key issue for the Hungarian nation, more than any time during its thousand years long presence in Europe. We need to know the world and the logic of empires and ideas that have shaped the history of mankind. And if we perceive new trends in time, it is only expedient to cooperate with them in pursuit of mutual benefits. For us this form of seeking a future and allies is still new, as our history is about phase delays and arrears from the global mainstreams. Now the historical opportunity 
is given for us to act with circumspection and carefully in repositioning our world economic relations, we may end up among the winners.

We could not directly enjoy the benefits of ancient civilisations. We did not even receive the due consideration for the cattle driven to the northern Italian markets live, as it was skimmed off by merchants. Technical development created a massively capitalised country for the purposes of the market that had spread to cover the entire world: the United States of America, which had grown from the British Empire. We were also a long way from that. And not only in the geographic sense of the word. Hungary was industrialised, feudalism was eliminated, and political and economic independence was won centuries after the developed countries considered as a standard. And let us add: although we had world-famous scientists, the socialization of our cultural and intellectual powers was also considerably delayed, also in time, but primarily in depth. We did not have a developed industry, we did not have an independent polity, and so culture, science and civilisation could not penetrate deep down in society in a way and in an extent in the countries we admire, where civilisation and knowledge have become forces that energise the economy and made these countries strong and advanced.

Since the mid-19th century, ideas have been governing the fate of the world more than ever. The fundamental tool of moderating the unbridled wish to maximise profits, which arises from the nature of the capitalist method of production, the sanctity of private property and its uncontrolled operation, and to reduce profit-making may entail the transformation of the ownership structure and a tighter state coordination of the market participants. And the prototype state for this model is the People's Republic of China, which has already outpaced the United States, a country that has been amortised by wars lost after World War II, and has achieved perhaps the only success by the full completion of the Cold War and obtained economic benefits from the collapse of the Soviet Union. True, its benefits are quickly consumed by its intervention in the most recent conflicts, and the dependence on raw materials of its industrial systems and its vulnerability due to expensive production is ever increasing. China, on the other hand, can produce cheaper and in a more organised manner, it is capable of retaining its raw material bases and build new markets. While China is on the rise, the United States is stagnating. And the European Union is weakening.

After Hungary's predecessor polities were regularly excluded from the benefits of global development, from the heydays of ancient cultures, from trade in the Mediterranean and markets going global, in the early 21st century why shouldn't it establish links with a trend coming from the Far East and appearing to be advantageous? After all, we are at the end of an era, and we know and feel it exists. In production, technology and innovation. The alternative solution, the other side would be the European Union and perhaps the western cultures, considered by many to decline. Repeated crises, dropping birth rates, ageing societies, helplessness in the face of migration waves, and most importantly, the absence of a comprehensive strategy. Europe will certainly not be the new epicentre of development. Fifteen to twenty years ago we thought that despite decline in the economic productivity and efficiency of our region, its internal 
peace and the stability of its society and environment provides a competitive edge. But this is no longer the case. The uninterrupted military conflicts of the United States, its chronic energy dependence, indebted public sector, the fast decline in its social cohesion, the outsourcing of industrial workplaces outside the boundaries of the USA, and its greedy consumer society offer a decreasingly attractive alternative for emerging Central European countries. It is a fair conclusion to moderate our external relations with the West and intensify them with the Far Eastern superpower. We should not discard the idea of our western integration and our deep embeddedness in the European Union, but we should not intensify it any further. Let us wait and give the euro area time to find its feet. We should not want to adopt the weakening currency of the weakening economic region at any cost, as this would be tantamount to giving up the instruments used by the National Bank of Hungary to support the economic policy. When the warriors of the Hunnic Empire deployed first against Roman provinces and then against Rome, they did not add to the allies of Romans, quite the contrary: it increased the other side, which offered a better alternative to Rome (at least) for the provinces, which hoped for their political independence through the Huns.

Economy management includes navigation, or the ability to create visions, an ability only a few people have. Excessive caution is just as risky as the absence of a concept. What is more, it kills off the dynamism of those who create visions and reduces the momentum for the country. Based on business logic, we should therefore trust concept-makers who refuse to take loans from any financial institution or to keep their savings in a bank. We should rather settle in the border region between west and east, trade and make friends with the emerging empires.

Budapest, Christmas 2019

Dr. Csaba Lentner, university professor Editor-in-chief of Polgári Szemle 